\title{
Land Use and Land Cover Dynamics Analysis of the Togodo Protected Area and Its Surroundings in Southeastern Togo, West Africa
}

\author{
Amah Akodéwou 1,2,3,*®D, Johan Oszwald ${ }^{4}$, Slim Saïdi ${ }^{1}$, Laurent Gazull ${ }^{1,2}$, Sêmihinva Akpavi ${ }^{3}$, \\ Koffi Akpagana ${ }^{3}$ and Valéry Gond ${ }^{1,2}$ (1) \\ 1 CIRAD, Forêts et Sociétés, 34398 Montpellier, France; slim.saidi@cirad.fr (S.S.); laurent.gazull@cirad.fr (L.G.); \\ valery.gond@cirad.fr (V.G.) \\ 2 Forêts et Sociétés, University Montpellier, CIRAD, 34398 Montpellier, France \\ 3 LBEV, Université de Lomé, Lomé 1515, Togo; semakpavi@gmail.com (S.A.); koffi2100@gmail.com (K.A.) \\ 4 UMR CNRS LETG 6554, Laboratory of Geography and Remote Sensing COSTEL, Université de Rennes 2, \\ 35043 Rennes, France; johan.oszwald@univ-rennes2.fr \\ * Correspondence: makodewou@gmail.com
}

Received: 18 May 2020; Accepted: 2 July 2020; Published: 6 July 2020

check for updates

\begin{abstract}
Assessing land use and land cover (LULC) change is essential for the sustainable management of natural resources, biodiversity conservation, monitoring food security, and research related to climate change and ecology. With increasingly rapid changes in LULC in response to human population growth, a better assessment of land use changes is more necessary than ever. Although a multitude of LULC assessment methods exists, none alone provides a clear understanding of changes and their underlying factors. This study analysed historical LULC changes over a temporal extent of 42 years (1974-2016) in the Togodo Protected Area and its surroundings, in Togo, by associating intensity and trajectory analyses, that are complementary but rarely associated in the literature. Our results show that LULC change in our study site is linked to the combined effects of human activities, climate, and invasive plants, particularly Chromolaena odorata. While each type of analysis provides useful insights, neither intensity nor trajectory analysis alone provides a full picture of changes and their causes. This study highlights the usefulness of associating intensity and trajectory analyses when implementing any management policy.
\end{abstract}

Keywords: land use change; intensity analysis; trajectory analysis; landscape dynamics; West Africa

\section{Introduction}

Human-induced landscape changes over the past 100 years were faster and deeper than ever before in human history [1,2]. Land use and land cover (LULC) change has contributed significantly to the improvement of human well-being and economic development. However, these gains are also accompanied by biodiversity loss and ecosystem degradation. Indeed, LULC change is a consequence of human-induced environmental change, but also one of the main drivers of both biodiversity loss and ecosystems changes worldwide [3,4]. The assessment of LULC changes and trajectories at the global, national, and local levels is, therefore, useful for sustainable development policies, monitoring food security, and climate change and environmental-related research [5].

The integration of remote sensing in combination with geographic information systems (GIS) has considerably advanced the assessment of land use change and landscape degradation at various scales [6-8]. The availability of an increasing range of remotely sensed imagery, such as Landsat archives, has enabled the development of databases and the assessment of landscape dynamics and trajectories $[9,10]$. Moreover, several methods have been developed by landscape researchers to analyse 
various landscape issues [11]. Two specific and popular methods have been shown to be invaluable for land use change assessment. The first of these is intensity analysis [12]. The second is the analysis of land cover change trajectories, aiding in better understanding the possible causes of LULC change and its effects [13].

Although intensity analysis and trajectory analysis complement each other well and are not redundant, to our knowledge they have rarely been associated in studies. However, the complementarity of these two analyses should lead to a better understanding of LULC changes. While intensity analysis, a quantitative approach that assesses measurements of change at three increasing levels, allows for a better understanding of the size and intensity of changes [12], trajectory analysis, which is based on the time series of each pixel, allows one to trace the history of land use change for every location in the study area.

Understanding the historical changes (trajectories) of LULC enlightens the environmental and social impacts of landscape change [14] and the historical processes that drive changes [15]. An analysis of LULC trajectories enables one to identify the direction and spatial distribution of changes for different LULC types to assess how landscapes change over time [10]. Such information is crucial for regions with rapid and growing landscape dynamics, such as West Africa. The periodic assessment of LULC changes in these regions is therefore essential to underpin policies such as biodiversity conservation, climate change, and sustainable development $[16,17]$.

In Togo, natural vegetation has undergone significant change as a result of human activities such as agricultural expansion, illegal tree logging, and incursions in protected areas $[13,17]$. Similarly, the Togodo Protected Area (TPA) and its surroundings are experiencing near-daily human threats, including poaching, clearing for agricultural purposes, logging, and charring for domestic needs and sale. The subsequent changes over the past few decades led to the spread of many invasive plants that threaten the biodiversity of the TPA and add to the workload of local farmers [18]. Human pressure in and around the TPA forced the forest administration, in order to preserve the biodiversity conservation status, to proceed to the requalification of the TPA in February 2005. During this requalification, a consensual delimitation was carried out, and part of the protected area was returned to the population, who agreed to abandon the cultivated lands within the new boundaries of the TPA. These land use changes make TPA a suitable site for the assessment of land use change analysis methods. To ensure that the TPA continues to play its role in conserving biodiversity, it is necessary to better manage not only the surrounding lands but also plant invasions.

However, the processes involved in historical land change in and around the TPA have hitherto received limited attention. Given the historical legacy of past land uses on invasion success [19], and the relationship between LULC change and land degradation, climate change, and the decline in biodiversity and related ecosystem services [3,20], it is crucial to investigate the processes involved in LULC change trajectories in the TPA. Understanding land use changes in the area will enable us to identify the landscape drivers that most influence the spread of invasive plants and their spatial distribution in a context of sometimes rapid land use changes.

The main objective of this study is to demonstrate how the association of intensity and trajectory analyses allows for a better understanding of LULC changes in and around the TPA. Thus, apart from its methodological aspect, our analysis aims to provide information on land use changes and their drivers in the area for better land and invasive plants management.

This study aims to analyse historical LULC changes and land transitions over a temporal extent of 42 years (1974-2016) in the TPA and its surroundings. Specifically, this study proposes to:

1. Identify and map the major LULC categories at the time points 1974, 1986, 2003, and 2016;

2. Determine the types and processes of LULC dynamics as well as their rate of occurrence; and

3. Analyse land change trajectories. 
This information will highlight the importance of combining intensity and trajectory analysis. Furthermore, it is useful for a better understanding of the effects of LULC dynamics on ecological phenomena and for sustainable natural resource management.

\section{Materials and Methods}

\subsection{Study Area}

The study was carried out in the Togodo Protected Area (TPA) and its surroundings (Figure 1) in southeastern Togo (West Africa). Agriculture is the main activity in the area. The climate is of the equatorial transition type, with rainfall of 1000 to $1300 \mathrm{~mm}$ per year and average monthly temperatures ranging from $25^{\circ} \mathrm{C}$ to $29^{\circ} \mathrm{C}$. The study site is dominated by Guinean wet savannahs with some patches of semi-deciduous dry and dense forests [21].

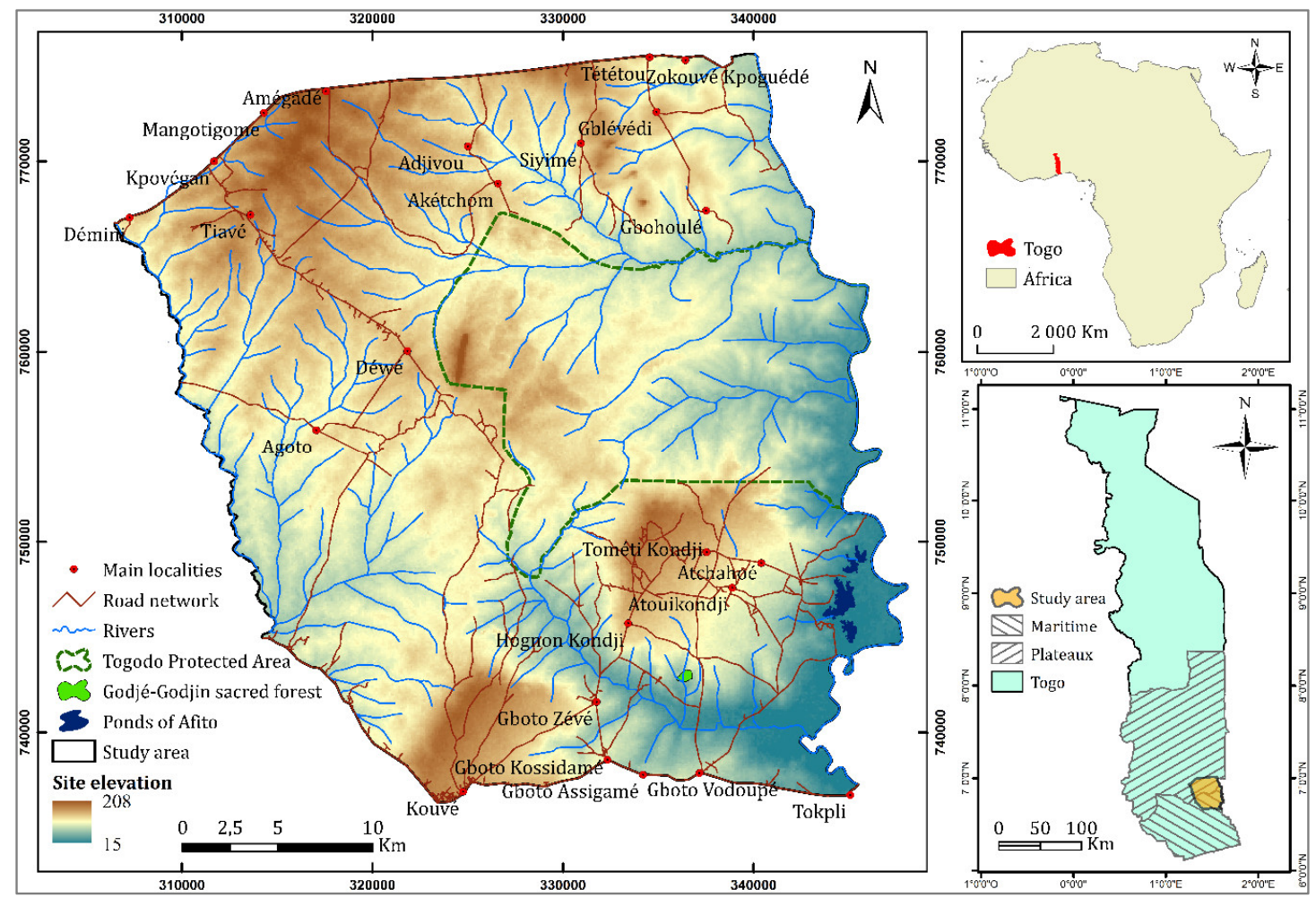

Figure 1. Location of the study area.

\subsection{Satellite Imagery}

Depending on the available cloud-free data, we chose multitemporal Landsat images and a single Sentinel 2 image for LULC maps of 1974, 1986, 2013, and 2016 for the TPA and its surroundings. Landsat images were acquired from the U.S. Geological Survey and the Sentinel 2 image from the ESA Copernicus website. We chose the Sentinel 2 image for the last time point because of its availability and high spatial resolution $(10 \mathrm{~m})$. Studies showed the high potential of Sentinel 2 images for improving the monitoring of tropical forests and savannahs [22,23]. For the selected years, we favoured acquisitions from the late rainy season and early dry season to obtain the maximum contrast between the different elements of the landscape [24]. All the images are projected in the UTM-WGS 1984 ZONE $31 \mathrm{~N}$ projection system. We resampled the Landsat 1 images from $60 \mathrm{~m}$ to $30 \mathrm{~m}$ resolution.

For a better multitemporal analysis, we performed radiometric and atmospheric (TOA to surface reflectance) corrections for all of the Landsat images [25] and the Sentinel 2 image [26]. Several invariant points (crossroads, reference buildings, etc.) distributed throughout the study area were used for the geometric correction of the Sentinel 2 image. Finally, we recalibrated all the archival Landsat images 
compared to the Sentinel 2 image and computed the Normalized Difference Vegetation Index (NDVI) as an independent layer. This index is widely used and allows one to minimize confusion between different types of land use that are similar to each other, such as dry forests and wooded savannahs, in savannah-dominated landscapes [17].

\subsection{Land Use and Land Cover Classification}

The classification was performed in ENVI software based on five LULC types, for Landsat images (Table 1), and in eCognition based on seven classes, for the Sentinel 2 image.

Table 1. Definition of the land use and land cover types used for the classification.

\begin{tabular}{ccc}
\hline & $\begin{array}{c}\text { Land Use and } \\
\text { Land Cover Type }\end{array}$ & Definition \\
\hline 1 & Forest & $\begin{array}{c}\text { Close canopy woody vegetation and riparian } \\
\text { forests }(>75 \text { trees per ha, a minimum height of } 5 \mathrm{~m} \\
\text { at maturity) }\end{array}$ \\
\hline 2 & Savannah & $\begin{array}{c}\text { Treeless open canopy vegetation ( }<75 \text { trees per ha) } \\
\text { with a mixture of shrub and scattered grasslands }\end{array}$ \\
\hline 3 & Cropland & $\begin{array}{c}\text { Agricultural land with crops (cereal, vegetable, } \\
\text { and fruits) and fallows less than 3 years }\end{array}$ \\
\hline 5 & Built area & $\begin{array}{c}\text { Areas occupied by settlements (cities, villages, } \\
\text { roads, and other building) }\end{array}$ \\
\hline & Water & Rivers, ponds, and reservoirs \\
\hline
\end{tabular}

\subsubsection{Classification of Landsat Images}

For the classification of LULC, we used the supervised Support Vector Machines (SVM) classifier approach [27]. Among the various supervised classifiers, the SVM algorithms are among the most powerful, flexible, and accurate [27-29]. Accurate training and validation datasets for each class were obtained by digitizing training class polygons based on the interpretation of pre-existing vegetation maps [30,31] containing information on past LULC, and by using our expert field knowledge. We applied to all Landsat output maps a majority filter of $5 \times 5$ pixels to remove the "salt and pepper" noise usually observed in satellite data [17].

\subsubsection{Classification of the Sentinel 2 Image}

According to the high resolution of the Sentinel 2 image and the heterogeneity of our site, an Object-Based Image Analysis (OBIA) [32] in eCognition Developer 9.0 software was used for the classification. OBIA does not treat the pixel in isolation, but in its spatial and spectral environment, by grouping pixels within interpreted objects based on their spectral values, size, shape, and context [33]. For the first step of classification, we opted for multi-resolution segmentation [34]. In the second step, we chose the heuristic approach of the expert system [35] for the classification. Thus, we formulated some user-defined knowledge rules for each type of object to be classified into land cover classes [36]. In addition to the classes used for Landsat images, we defined fallow and plantation classes (oil palm and teak plantation). We validated our classification with ground-truth datasets collected during field surveys (November to December 2016).

\subsection{Accuracy Assessment}

We computed the quantity disagreement, allocation disagreement, and overall accuracy for each LULC map following [37]. To this end, we entered the confusion matrix into a spreadsheet available free of charge at www.clarku.edu/ \{\}rpontius. To summarize a cross-tabulation matrix, the measures 
of quantity disagreement and allocation disagreement are much more useful than the various Kappa indices $[37,38]$.

\subsection{Land Use and Land Cover Change Assessment}

We assessed the LULC changes through land use intensity and trajectory analyses. To that end, after exporting the output images to ArcGIS software, we adopted post-classification comparisons for change detection analyses of the individual LULC maps [17,39]. We computed class statistics and transitions analyses from the output LULC maps for each LULC type and transition category for the time intervals 1974-1986, 1986-2003, and 2003-2016. To assess LULC changes, we used the resulting contingency tables for the land use intensity analysis.

\subsubsection{Intensity Analysis}

Intensity analysis $[12,40]$ is a quantitative approach that assesses measurements of change at three increasing levels (interval level, category level, and transition level).

The first level determines how the annual change percentage (Equation (1)) varies compared to a uniform annual change (Equation (2)).

$$
\begin{gathered}
S_{t}=\frac{\text { (size of change during } \left.\left[Y_{t}, Y_{t+1}\right]\right) 100 \%}{\left(\text { size of spatial extent) }\left(\text { duration of }\left[Y_{t}, Y_{t+1}\right]\right)\right.} \\
U=\frac{\text { (size of change during all intervals) } 100 \%}{\text { (size of spatial extent)(duration of all intervals) }}
\end{gathered}
$$

The second level compares, for each category, a uniform intensity $S_{t}$ to the intensity of loss $L_{t i}$ (Equation (3)) and the intensity of gain $G_{t j}$ (Equation (4)) during each time interval $\left[Y_{t}, Y_{t+1}\right]$.

$$
\begin{aligned}
L_{t i} & =\frac{\left(\text { size of loss of } i \text { during }\left[Y_{t}, Y_{t+1}\right]\right) 100 \%}{\left(\text { size of } i \text { at time } Y_{t}\right)\left(\text { duration of }\left[Y_{t}, Y_{t+1}\right]\right)} \\
G_{t j} & =\frac{\left(\text { size of gain of } j \text { during }\left[Y_{t}, Y_{t+1}\right]\right) 100 \%}{\left(\text { size of } j \text { at time } Y_{t+1}\right)\left(\text { duration of }\left[Y_{t}, Y_{t+1}\right]\right)}
\end{aligned}
$$

Finally, the last level compares, during an analysed time interval, the transition intensity $R_{t i j}$ (Equation (5)) from category $i$ to category $j$ to a uniform transition intensity $W_{t j}$ (Equation (6)), given the gain of category $j[12]$.

$$
\begin{gathered}
R_{t i j}=\frac{\left(\text { size of transition from } i \text { to } j \text { during }\left[Y_{t}, Y_{t+1}\right]\right) 100 \%}{\left(\text { size of } i \text { at time } Y_{t}\right)\left(\text { duration of }\left[Y_{t}, Y_{t+1}\right]\right)} \\
W_{t j}=\frac{\left(\text { size of gain of } j \text { during }\left[Y_{t}, Y_{t+1}\right]\right) 100 \%}{\left(\text { size of not } j \text { at time } Y_{t}\right)\left(\text { duration of }\left[Y_{t}, Y_{t+1}\right]\right)}
\end{gathered}
$$

\subsubsection{Trajectory Analysis}

A LULC change trajectory is the succession of LULC types for a given sample unit over more than two time points $[10,39]$. For a given sampling unit, the number of trajectories $(\mathrm{N})$ is $N=n^{x}$, where $\mathrm{n}$ is the number of land cover classes and $x$ the number of time points observed. In our study, we used four time points $(1974,1986,2003$, and 2016) and five classes for each time point, except for the first time point (1974), for which the water class was not detected (Figure 2). Our analysis should have led to a number of trajectories $N=4 \times 5^{3}=500$. However, not all possible trajectories were detected. Moreover, we limited our analysis to the impacts of extensive agriculture on forests and savannahs. Indeed, agricultural expansion is one of the main driving forces of landscape change in the study area [41]. To simplify the analysis, we coded the LULC types from 1 to 5: 1-Forest, 2-Savannah, 
3-Cropland, 4-Built or bare area, and 5-Water [42]. We then computed the change trajectories using the ArcGIS 10.3 raster calculator.

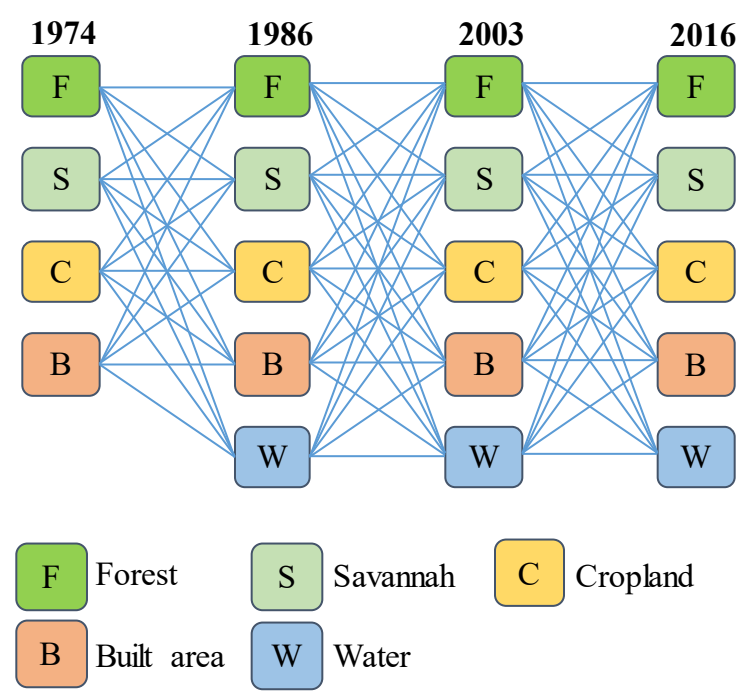

(A)

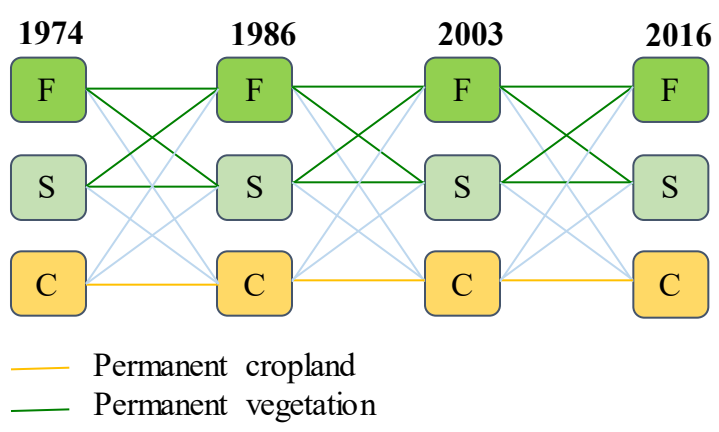

(B)

Figure 2. Land use and land cover trajectories: (A) Possible trajectories, (B) Example of main trajectories.

Since the purpose of our analysis was to understand the impacts of agriculture on natural vegetation, we combined trajectories considering forest and savannah as one natural vegetation class [13]. Likewise, all trajectories involving built areas and/or water were grouped under a single trajectory: "other".

\subsection{Climatic Trends}

To evaluate the possible significant effects of climate on the observed land use changes, we assessed the yearly amount of rainfall received by Tabligbo station from 1970 to 2018, provided by [43]. We used a graphical analysis and smoothed it with the moving average methodology to reduce the inter-annual variability. To define a wet or a dry year, we used the quantiles, the standard deviations, and the percentage of annual rainfall from the median or the mean [44]. In the context of a Guinean climate, we defined a dry year and a wet year based on the normalized precipitation index [45].

\section{Statistical Analysis}

To determine if Tabligbo station had been affected by a dry or wet climate trend over the period 1970-2018, we used the z-score transformation test [46]. This test allows one to compare the average values of two selected periods to the z-score transformation table with a 0.05 probability of error (Equation (7)).

$$
Z=\left|\mu_{1}-\mu_{2}\right| / \sqrt{\left[\left(\sigma_{1}^{2} / n_{1}\right)+\left(\sigma_{2}^{2} / n_{2}\right)\right]}
$$


where

Z: z-score transformation test;

$\mu_{1}$ and $\mu_{2}$ : rainfall averages of the two periods;

$\sigma_{1}^{2}$ and $\sigma_{2}^{2}$ : variances of the two samples;

$n_{1}$ and $n_{2}$ : number of years observed.

\section{Results}

\subsection{Land Use and Land Cover Maps and Contingency Table}

Over the last 42 years, the TPA and surrounding areas have undergone notable LULC change (Figures 3 and 4). Natural vegetation (Savannah and Forest) dominated the landscape at the early time intervals and decreased from $67 \%$ in 1974 to $64 \%, 42 \%$, and $22 \%$, respectively, in 1986, 2003, and 2016 (Appendix A). Savannah and Cropland were the most dominant LULC categories. Savannah decreased from 71,554.06 ha (60\%) in 1974 to $19,696.13$ ha (17\%) in 2016, while Cropland increased from $39,371.74$ ha $(33 \%)$ in 1974 to $91,498.8$ ha $(77 \%)$ in 2016 . The smallest categories were Water and Built area. For each time point, their area was less than $1 \%$.

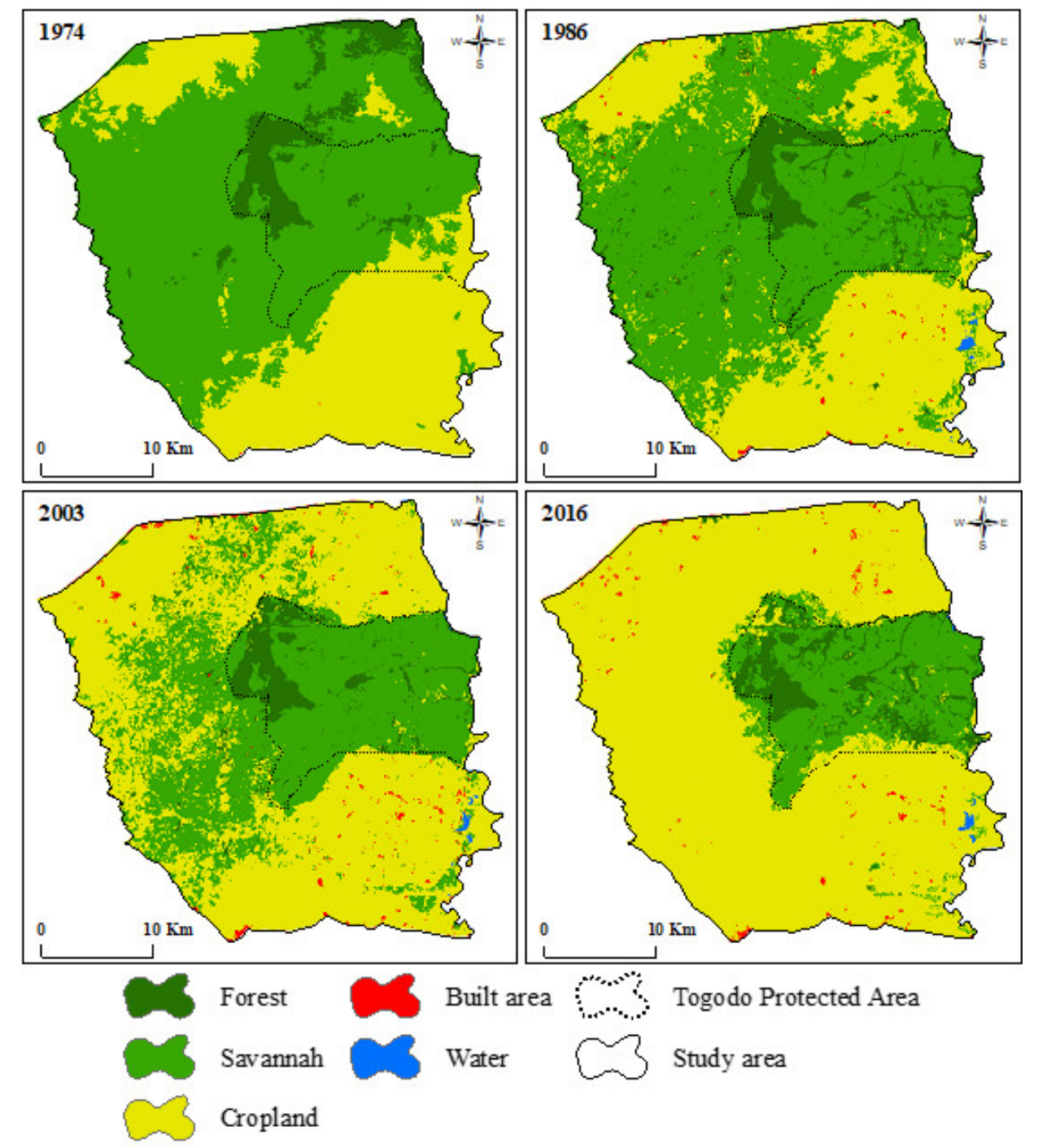

Figure 3. Maps of LULC categories in and around the Togodo Protected Area in 1974, 1986, 2003, and 2016. 

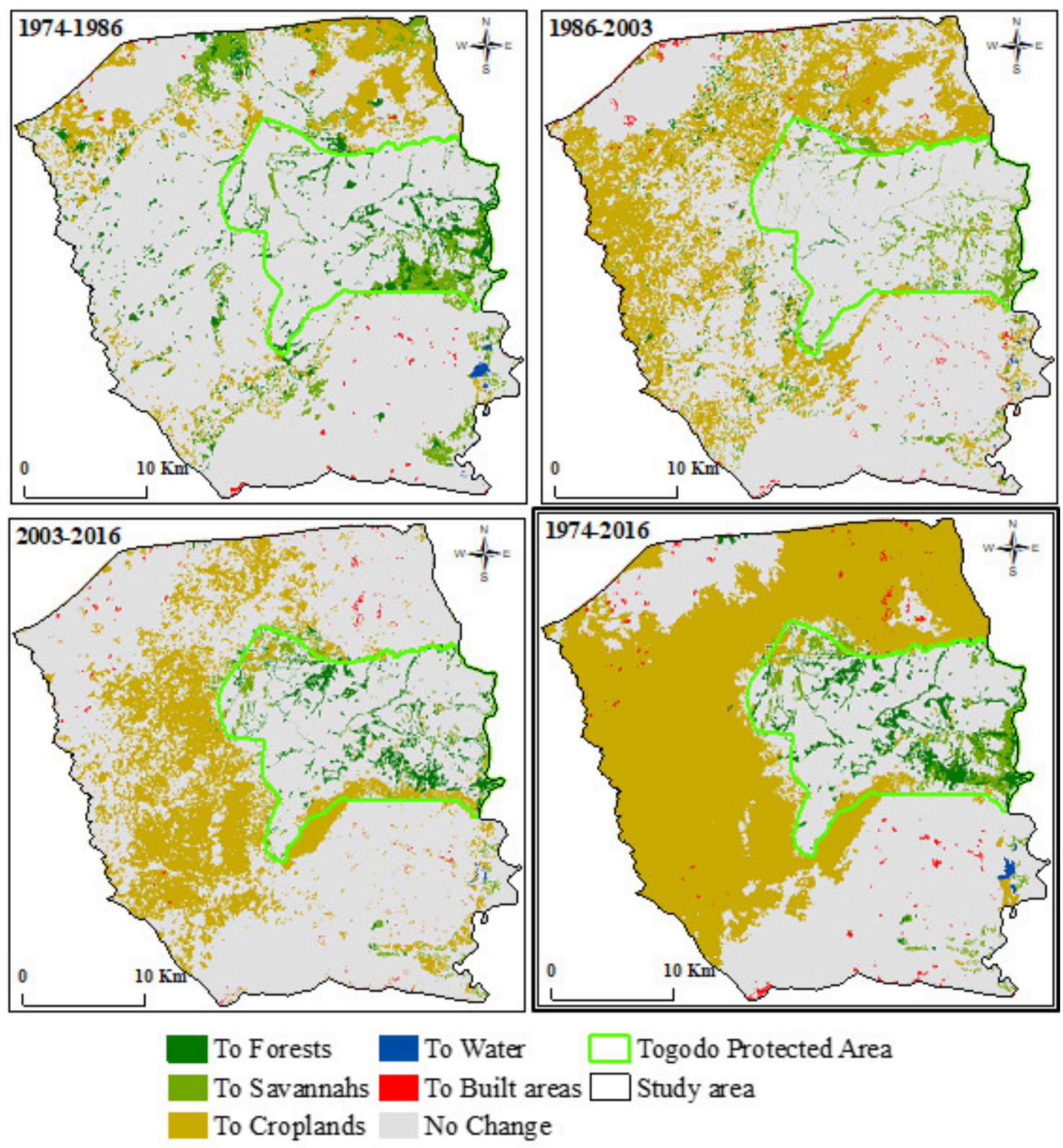

Figure 4. Historical LULC change in and around the Togodo Protected Area during the time intervals 1974-1986, 1986-2003, 2003-2016, and the temporal extent 1974-2016 (thick border).

\subsection{Time Interval Level Intensity Analysis}

Since large intensities frequently derive from small categories [12], and as our purpose is to understand the impacts of agriculture on natural vegetation, we do not present and analyse the results of land use intensity analysis for Water and Built area.

The results of time interval level intensity analysis (Figure 5) show that the annual change percentage (bars on the right of the central axis) was greater during the third time interval than during the second time interval, and during the second time interval than during the first. Land change was fast during the third time interval $(1.98 \%)$ and slow during the first $(1.53 \%)$ and second $(1.69 \%)$ time intervals. 


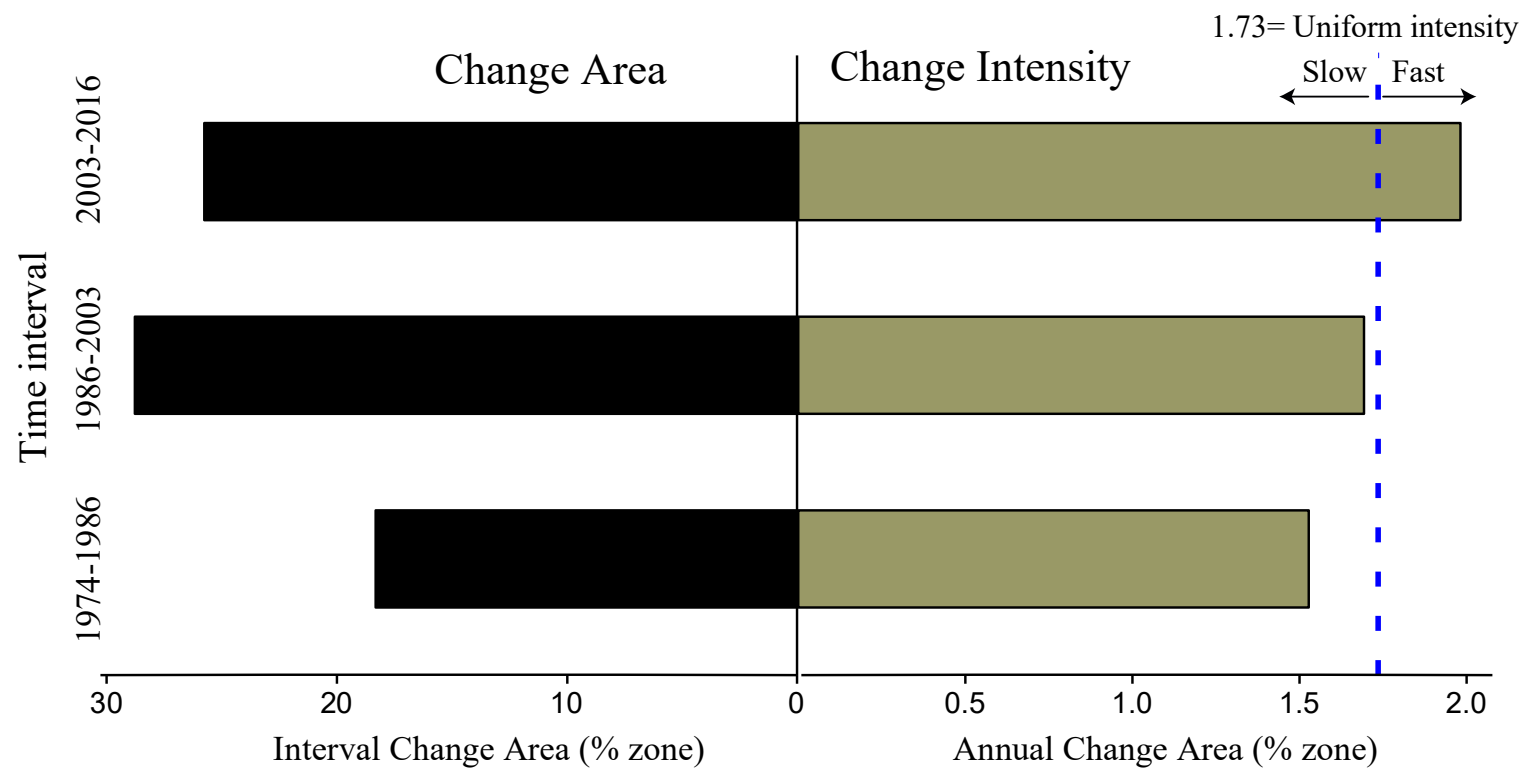

Figure 5. Time interval level intensity analysis.

The dashed line indicates the uniform annual change percentage during the temporal extent.

\subsection{Category Level Intensity Analysis}

Figure 6 presents the results from the category level intensity analysis. The annual change (bars on the left) shows that Cropland experienced more gain than loss during all time intervals, while Savannah experienced more loss than gain. Forest gained more during the first time interval (1974-1986) and the third time interval (2003-2016), whereas in the second time interval (1986-2003) Forest experienced a net loss.
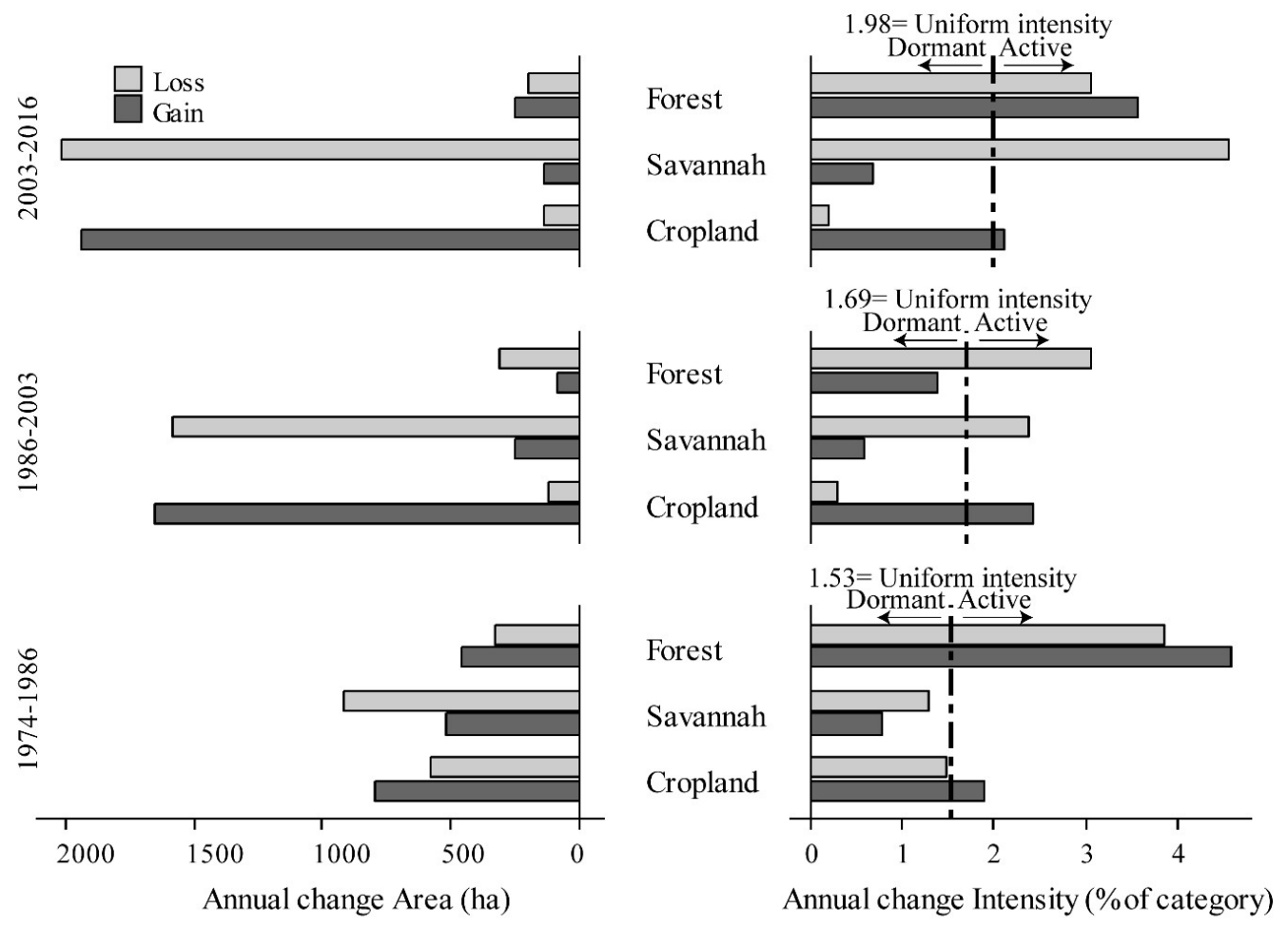

Figure 6. Category level intensity analysis. 
Cropland had active gains and Savannah has active losses during all time intervals except the first time interval, during which Savannah had a dormant loss due to Savannah's large size (60\% of area extent). Forest had active losses and gains, except during the second time interval, in which Forest gain was dormant.

The dashed line indicates uniform intensity, i.e., the intensity if the changes have been equally distributed over the spatial extent during the time interval.

\subsection{Transition Level Intensity Analysis}

The most important transition in terms of size was from Savannah to Cropland, followed by the transition from Forest to Cropland (Table 2). Regarding transition intensities, Forest's gain targeted Savannah, in particular, and avoided Cropland during all time intervals. Conversely, Savannah's gain derived mainly from Forest. Cropland's gain targeted Forest and avoided Savannah during the first time interval, although the size received from Savannah was higher than that received from Forest. During the second and the third time interval, Cropland's gain targeted Savannah and avoided Forest.

Table 2. Transition level intensity analysis.

\begin{tabular}{|c|c|c|c|c|c|c|c|c|c|c|c|}
\hline \multirow{4}{*}{$\begin{array}{c}\begin{array}{c}\text { From } \\
\text { Category }\end{array} \\
\text { Forest }\end{array}$} & \multirow{2}{*}{$\begin{array}{c}\begin{array}{c}\text { Time } \\
\text { Interval }\end{array} \\
1974-1986\end{array}$} & \multicolumn{2}{|r|}{ Forest } & \multicolumn{3}{|c|}{ Savannah } & \multicolumn{3}{|c|}{ Cropland } & \multirow{2}{*}{$\begin{array}{c}\text { Sum } \\
7.0\end{array}$} & \multirow{2}{*}{$\begin{array}{r}\text { Loss } \\
3.3\end{array}$} \\
\hline & & 3.8 & & 1.2 & 1.4 & $T a$ & 2.0 & 2.4 & $T a$ & & \\
\hline & 1986-2003 & 4.0 & & 2.3 & 1.6 & $T a$ & 2.0 & 1.4 & $A v$ & 8.4 & 4.4 \\
\hline & 2003-2016 & 3.1 & & 0.7 & 1.1 & $T a$ & 1.3 & 2.0 & $A v$ & 5.2 & 2.1 \\
\hline \multirow{3}{*}{ Savannah } & 1974-1986 & 3.3 & 0.5 & 50.7 & & & 5.9 & 0.8 & $A v$ & 60.0 & 9.2 \\
\hline & 1986-2003 & 0.9 & 0.1 & 33.4 & & & 21.4 & 2.3 & $T a$ & 56.0 & 22.5 \\
\hline & 2003-2016 & 2.4 & 0.5 & 15.0 & & & 19.5 & 4.1 & $T a$ & 37.0 & 22.0 \\
\hline \multirow{3}{*}{ Cropland } & 1974-1986 & 1.3 & 0.3 & 4.0 & 1.0 & $A v$ & 27.2 & & & 33.0 & 5.8 \\
\hline & 1986-2003 & 0.3 & 0.1 & 1.2 & 0.2 & $A v$ & 33.5 & & & 35.1 & 1.7 \\
\hline & 2003-2016 & 0.3 & 0.0 & 0.7 & 0.1 & $A v$ & 55.6 & & & 57.0 & 1.4 \\
\hline \multirow{3}{*}{ Sum } & 1974-1986 & 8.4 & & 56.0 & & & 35.1 & & & 100.0 & 18.3 \\
\hline & 1986-2003 & 5.2 & & 37.0 & & & 57.0 & & & 100.0 & 28.8 \\
\hline & 2003-2016 & 5.9 & & 16.5 & & & 76.7 & & & 100.0 & 25.8 \\
\hline \multirow{3}{*}{ Gain } & 1974-1986 & 4.6 & & 5.2 & & & 8.0 & & & 18.3 & \\
\hline & 1986-2003 & 1.2 & & 3.6 & & & 23.6 & & & 28.8 & \\
\hline & 2003-2016 & 2.7 & & 1.5 & & & 21.1 & & & 25.8 & \\
\hline \multirow{3}{*}{$W_{t j}$} & 1974-1986 & 0.4 & & 1.1 & & & 1.0 & & & & \\
\hline & 1986-2003 & 0.1 & & 0.5 & & & 2.1 & & & & \\
\hline & 2003-2016 & 0.2 & & 0.2 & & & 3.8 & & & & \\
\hline
\end{tabular}

For each transition (from row categories to column categories), the first column indicates the proportions of inter-categorical transitions (persistence and transitions). The second column (numbers in bold) indicates the transition intensities. The third column gives the meaning (Ta: Target and Av: Avoid) of the transition intensity in comparison with the uniform intensity $W_{t j}$. The size of each category in the initial time point of each time interval is presented in the Sum column, on the right. The Sum row at the bottom indicates the size of each category in the last time point of each time interval. The Loss column is the Sum at the initial time point minus the persistence. The Gain row is the Sum at the final time point minus the persistence. The $\mathrm{W}_{\mathrm{tj}}$ row at the bottom presents the uniform intensity (gain intensity of column category $j$ if the gain were to have been uniformly transitioned from the space different from $j$ ).

\subsection{Trajectory Analysis}

Appendix B summarizes the definition and the area proportion of land change trajectories illustrated in Figure 7. Appendix B shows that approximately $25 \%$ of the study area was permanently cultivated (Permanent cropland), while 20\% was permanently without agricultural activities (Permanent 
vegetation) over the temporal extent of 42 years (1974 to 2016). Between 2003 and 2016, 21\% of the area was converted to cropland (Recent cropland) from forest and savannah. Similarly, around 23\% (Young cropland) and 7\% (Old cropland) were converted to cropland, respectively, during 1986-2003 and 1974-1986. For each time interval, the abandoned cropland area was less than $2 \%$ and decreased from $1.52 \%$ (Old reforestation) to $0.01 \%$ (Recent reforestation). Vegetation areas cultivated then abandoned and cropland abandoned then recultivated (Cropland-fallow cycle) represent less than $1 \%$ of the study area.

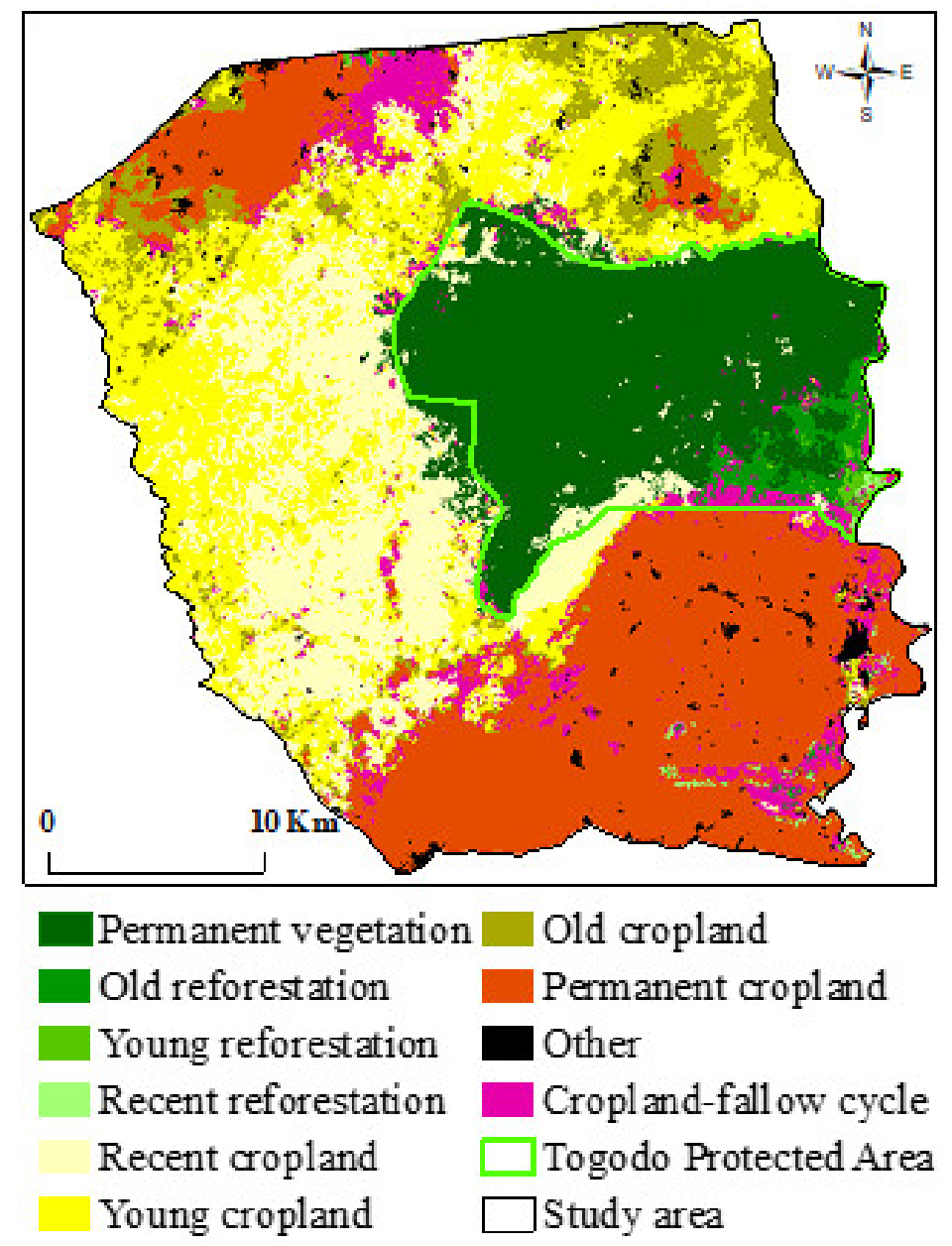

Figure 7. Map of land change trajectories for 1974-1986-2003-2016 in and around the Togodo Protected Area.

\subsection{Long-Term Annual Rainfall Data Analyses}

Based on the rainfall data, the average annual rainfall calculated during the growing season on a series of 49 years (1969-2018) is about $1061 \mathrm{~mm}$ (standard deviation: $\pm 142 \mathrm{~mm}$ ), with low inter-annual variability and a rainfall coefficient of variation of about $13 \%$. Figure 8 shows the common discontinuities in the 1970-2018 time series, with alternating dry and wet periods with variable durations. The moving averages curve shows that there is a difference between the two periods: 1970-2000 and 2000-2018. The yearly rainfall trend after 2000 indicates that the annual rainfall was above the average for 18 years (2000-2018). Although this period displays a net increasing rainfall, the series of 49-years observed (1969-2018) are insufficient in terms of rainfall data to affirm a wet trend. However, our graph indicates that a drier trend does not seem to be affecting the Tabligbo region. 


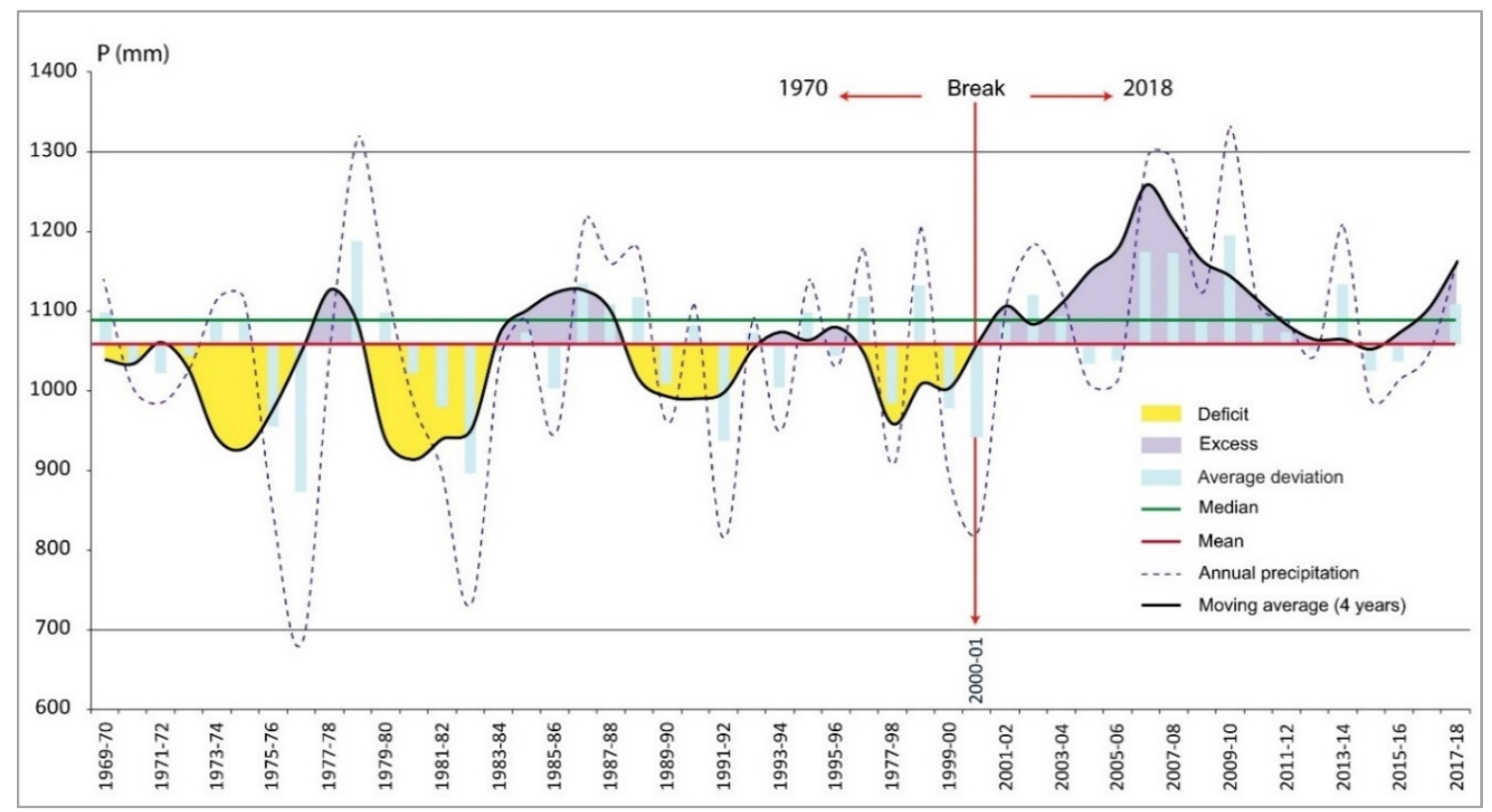

Figure 8. Annual rainfall totals for Tabligbo meteorological station.

Table 3 shows that dry sequences vary between 1 and 3 years, with an average value of 1.5 years. During the period studied, we noticed that three successive years was the longest sequence for dry years, while the longest sequence for normal years consisted of five successive years. The wet years and those called "normal" account for $73 \%$ of the years observed, compared with $27 \%$ for dry years (Table 3).

Table 3. Frequency of dry, normal, and wet sequences in the Tabligbo meteorological station (1970-2018).

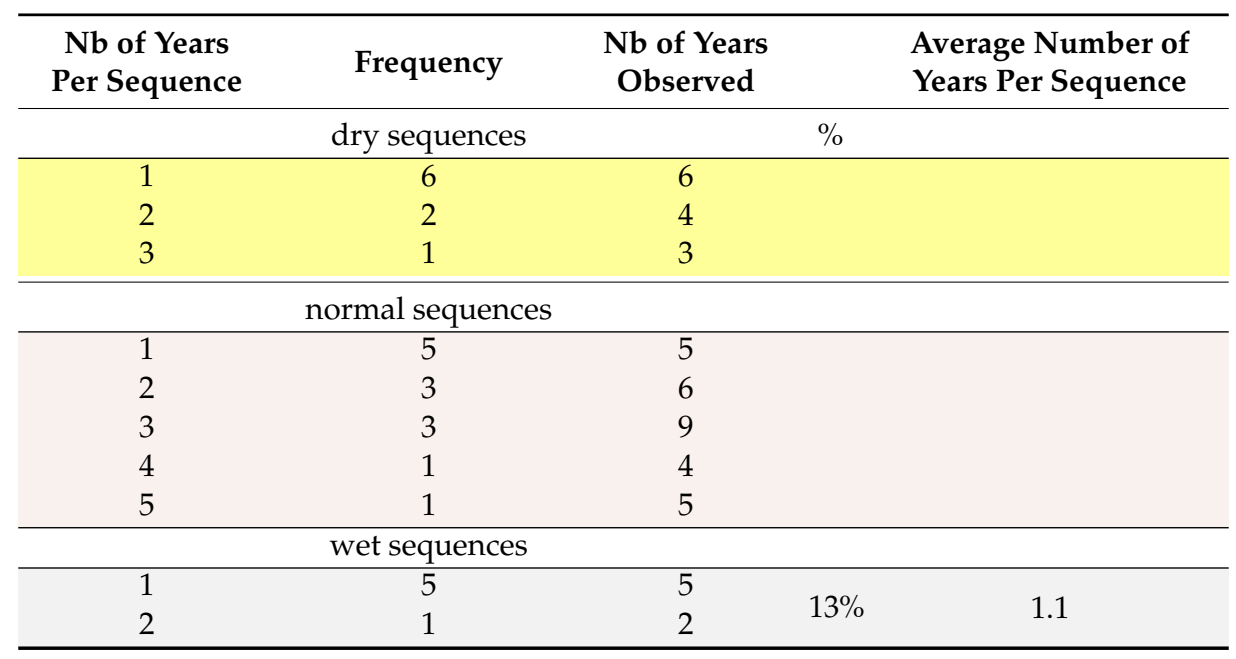

Table 4 presents the z-score transformation results. The average rainfall recorded by the station increased by $10 \%$ between the two periods. However, the z-score transformation value was higher than 1.96 (5\% risk threshold), indicating that the difference between the two average rainfall values for the two periods considered is significant. According to this result, Tabligbo station shows a convincing general wet trend cycle between 2000 and 2018. 
Table 4. z-score transformation test.

\begin{tabular}{ccc}
\hline & Period (1970-2000) & Period (2001-2018) \\
\hline Average values $\left(\mu_{1}\right.$ and $\left.\mu_{2}\right)$ & 1026 & 1128 \\
Number of years observed $(N)$ & 32 & 17 \\
Standard deviation $(\sigma)$ & 147 & 106 \\
z-score transformation test $(Z)$ & & 2.77 \\
\hline
\end{tabular}

\section{Discussion}

In West Africa, forests and savannahs are undergoing significant changes due to agricultural expansion. The assessment and monitoring of LULC changes are therefore important in this region to identify suitable management policies that allow LULC change dynamics to be mitigated and steered towards desired outcomes [47]. This study, while filling a gap in information on historical LULC change in the TPA, aims to highlight the usefulness of associating intensity and trajectory analyses for a better understanding of LULC changes. We combined these analyses to assess LULC changes over a temporal extent of 42 years (1974-2016). While intensity analysis provides a good understanding of the transition intensities among land categories [12,48], trajectory analysis provides complementary information, namely the spatial distribution of changes over different time intervals $[10,13]$.

\subsection{LULC Mapping and Accuracy}

The overall accuracies (Appendix C) of our classification are higher than $80 \%$, except for the 1974 map. In an area as complex as ours, with small parcel sizes, the overall accuracies of $76.79 \%$ and $82.46 \%$ (less than the $85 \%$ target value) seem quite relevant for LULC change analysis $[49,50]$. In Togo, in similar contexts, accuracies of the same order of magnitude have been obtained by several studies $[13,17,22]$. Similar accuracies were also obtained on historical images of the Amazon [24]. The relatively low accuracy of the Landsat 1 MSS images classification could be explained by the image resolution and the limited number of spectral bands compared to other images.

Natural vegetation dominated the TPA and its surroundings for the first and the second time points (1974 and 1986), while cropland dominated the study area for the two subsequent time points (2003 and 2016). During all the time intervals and temporal extents, savannah substantially decreased. In contrast, cropland increased slightly between 1974 and 1986 before showing an acute increase during the second and third time intervals. The rapid expansion of cultivated land at the expense of savannah and forest indicates that extensive agriculture is the major cause of landscape changes in our study area. Indeed, agricultural practices such as clearing savannah and forest for cultivation or planting (teak and oil palm) and fallowing are the dominant drivers affecting the landscape dynamics in the study area [41]. Similarly, different areas of Togo such as Yoto Prefecture [51], around the Fazao-Malfakassa National Park [22], and the Kara river basin [13], have undergone a conversion of natural vegetation into agricultural areas leading to the degradation of natural resources.

\subsection{Influence of Climate, Human Actions, and Invasive Plants}

Forest experienced a net gain during the first and third time intervals. This gain took place mainly within the protected area and targeted Savannah. For the first time interval, forest gain might probably be due to the low resolution of the 1974 Landsat 1 image coupled with the drought of the 1970s in West Africa. Indeed, our analysis of rainfall shows that the period from 1970 to 2000 was rather dry. The year 1974 was very dry, while 1986 was relatively wet. With the drought, forests would be less photo-reflective, and with a resolution of $60 \mathrm{~m}$, edges and gallery forests would be difficult to detect. The drought would be responsible for the drying out of Water (ponds) that we do not detect in the 1974 image. Indeed, climate variability can affect vegetation cover in West Africa [52,53]. To limit confusion due to the low resolution of the image, the ideal would be to use higher-resolution images. 
Unfortunately, apart from aerial photographs that are not (or only rarely) available in our study area, Landsat images remain the only sources for historical analyses dating back to the 1970s.

Forest gain during the third time interval would be related to human activities within the protected area. The low level of enforcement of protection laws has led to a series of cultivation and fallow abandonment within the protected area. On the one hand, these fallows have evolved into savannahs and then forests. Other studies in Togo have also reported the dynamics of fallows turning into forests through forest regrowth [18]. On the other hand, a dense and photo-reflective cover of Chromolaena odorata (Figure 9) dominates the young fallows at the edges of the forests. Therefore, these fallows with $C$. odorata could resemble-and be confused with-the forest. In fact, open areas and forest canopy gaps are the optimal niches for the establishment and spread of the invasive shrub species $C$. odorata [54]. To reduce the confusion induced by C. Odorata, the use of very high-resolution images would be a solution, and the recent use of drones in remote sensing is an option to be explored.

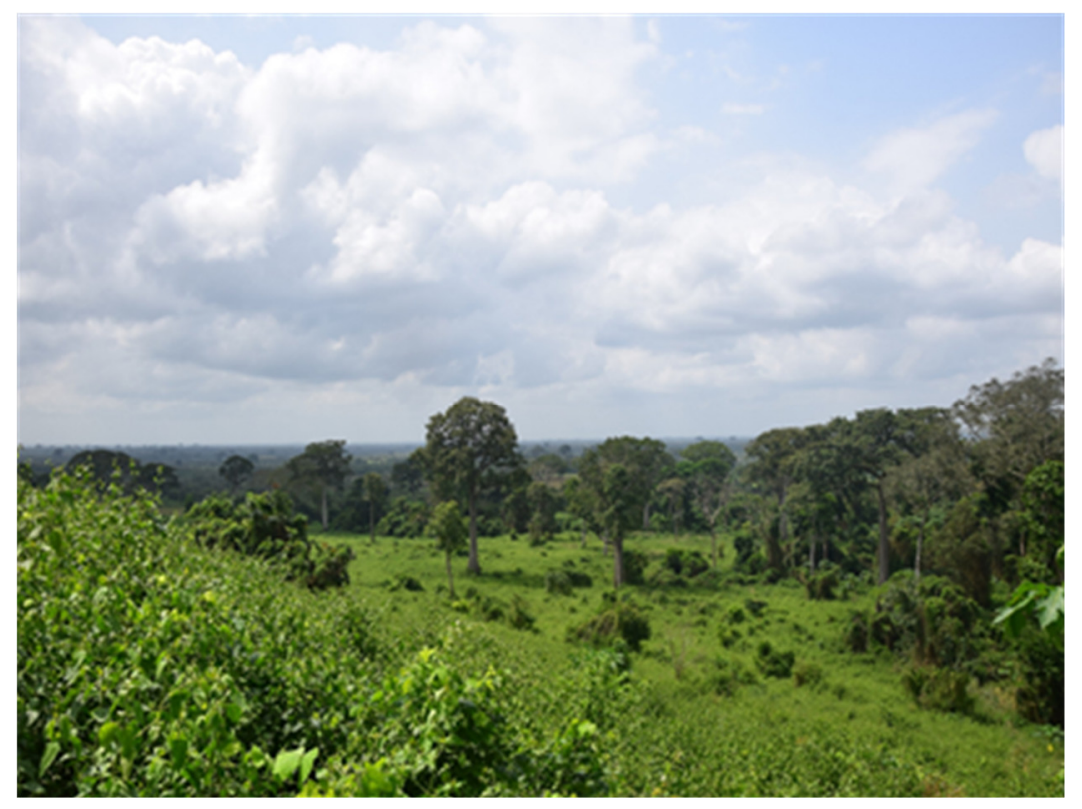

Figure 9. Dense and highly photo-reflective cover of Chromolaena odorata in degraded forests at the edge of the Togodo Protected Area.

\subsection{Increasing Anthropogenic Pressures}

From the first time interval to the third, there is an increasing intensity of change. Less and less cropland is abandoned to fallow, and fallow cycles, therefore, become shorter and shorter. Besides, the first croplands (Permanent cropland) located in the northwestern, northeastern, and southeastern parts of the site gradually widened towards the protected area, which remains the only remnant of natural vegetation. This increasing intensity and trajectory of croplands are the consequences of increasing anthropogenic pressures resulting from population growth and the consequent increase in food and energy demand, requiring more land for agricultural production [55]. Indeed, the population density of Maritime and Plateaux, the two regions incorporating the study area, increased from 105 and 38 inhbts $/ \mathrm{km}^{2}$ in 1981 to 280 and 81 in 2010, respectively [56]. During the same period, their growth rates almost tripled (3.16\% and $2.58 \%$ ). Currently, the biodiversity conservation status of the TPA is under serious threat. While population growth continues, there is no longer any natural vegetation that could be cleared outside of the protected area. There is, therefore, an urgent need to review agricultural production systems and protected area management policies. Promoting agroecology, agroforestry, and the use of compost could be a solution to restore and maintain field fertility. 


\subsection{The Usefulness of Associating Intensity and Trajectory Analysis}

Without trajectory analyses, it would be difficult to properly locate LULC changes. The location of the changes made it possible to identify, within the framework of this study, the extent to which climate factors contributed to the changes observed between 1974 and 1986. Likewise, the location of the changes made it possible to highlight the effect of $C$. odorata fallows. Meanwhile, the intensity analysis showed that the changes are becoming more intense and are mainly linked to anthropogenic pressures. While each analysis provides useful data, when considered in isolation, it cannot provide a full picture of the changes and their causes. This constitutes an obstacle to the implementation of appropriate management policies. Associating intensity and trajectory analysis makes it possible to specify the share resulting from natural climate changes (droughts, for example) and that resulting from human activities. This avoids imprudently attributing to human actions the entire evolution of the environment [57].

\section{Conclusions}

To sum up, this study filled a gap in monitoring data on LULC change in the TPA and its surroundings by analysing the historical LULC changes and land transitions over a temporal extent of 42 years (1974-2016). We assessed LULC changes by combining intensity and trajectory analysis. Overall, the results show that during the temporal extent studied, the TPA and its surroundings experienced notable changes. Vegetation cover (forests and savannahs) experienced a decrease from $67 \%$ to $22 \%$, while cultivated land increased from $33 \%$ to $77 \%$. Savannah and Cropland respectively decreased and increased gradually during the study period, while Forest experienced a sawtooth dynamic. The irregular dynamics of Forest are thought to be linked to the combined effect of human activities, climate, and invasive plants, particularly C. odorata. Furthermore, our results show that human activities, including agricultural practices such as clearing savannah and forest for cultivation and fallowing, are the main factors driving landscape dynamics. The combination of intensity and trajectory analyses not only allows for a better understanding of spatio-temporal dynamics but also renders it possible to link drivers with processes of LULC change in our study site. We therefore recommend that decision-makers always consider these two complementary analyses when implementing any management policy. Nevertheless, additional studies are necessary to enhance the accuracy of LULC mapping, particularly to distinguish between C. odorata fallows and forests.

Author Contributions: Conceptualization, A.A. and S.A.; formal analysis, A.A. and S.S.; funding acquisition, K.A.; investigation, A.A., J.O., K.A., and V.G.; methodology, A.A. and S.A.; resources, L.G. and V.G.; supervision, V.G.; validation, J.O.; visualization, V.G.; writing-original draft, A.A. and S.S.; writing-Review \& editing, J.O. and L.G. All authors have read and agreed to the published version of the manuscript.

Funding: This article is part of the first author's Ph.D. work, which was supported by the Islamic Development Bank (IsDB) under its Merit Scholarship Program [no. 36/11210124 of 2015].

Acknowledgments: The authors would like to thank Wouyo Atakpama for his help during the fieldwork. We greatly appreciate the assistance provided by Florent Rumiano and Badabate Diwediga during our analysis. We extend our thanks to Grace Delobel and Ayi Segniagbeto for their careful proofreading of the manuscript.

Conflicts of Interest: The authors declare no conflict of interest. 
Appendix A. Areal Distribution of the LULC Categories in and around the Togodo Protected Area in 1974, 1986, 2003, and 2016.

Table A1. Areal Distribution of the LULC Categories in and around the Togodo Protected Area in 1974, 1986, 2003, and 2016.

\begin{tabular}{cccccccccc}
\hline LCC & $\mathbf{1 9 7 4}$ & $\begin{array}{c}\text { Areas } \\
\text { (ha) }\end{array}$ & $\mathbf{1 9 8 6}$ & $\begin{array}{c}\text { Areas } \\
\text { (ha) }\end{array}$ & $\mathbf{\%}$ & $\begin{array}{c}\text { Areas } \\
\text { (ha) }\end{array}$ & \% & $\begin{array}{c}\text { Areas } \\
\text { (ha) }\end{array}$ & \% \\
\hline Forests & 8388.75 & 7.03 & 9988.31 & 8.37 & 6240.35 & 5.23 & 6994.36 & 5.86 \\
Savannahs & $71,554.06$ & 59.97 & $66,779.63$ & 55.97 & $44,151.83$ & 37.00 & $19,696.13$ & 16.51 \\
Croplands & $39,371.74$ & 33.00 & $41,915.87$ & 35.13 & $68,050.69$ & 57.03 & $91,498.8$ & 76.68 \\
Built areas & 8.49 & 0.01 & 357.73 & 0.30 & 521.32 & 0.44 & 790.06 & 0.66 \\
Water & 0.00 & 0.00 & 281.50 & 0.24 & 358.85 & 0.30 & 343.69 & 0.29 \\
\hline
\end{tabular}

Appendix B. Land Change Trajectories Definition and Proportion.

Table A2. Land Change Trajectories Definition and Proportion.

\begin{tabular}{|c|c|c|c|}
\hline Trajectory Classes & Definition & Trajectories & Percentage of Area $(\%)$ \\
\hline Permanent cropland & $\begin{array}{l}\text { At least } 42 \text {-years } \\
\text { permanent cropland }\end{array}$ & $\operatorname{CCCC~}(\mathrm{CCCC})$ & 25.28 \\
\hline Permanent vegetation & $\begin{array}{l}\text { At least 42-years } \\
\text { permanent forest } \\
\text { or savannah }\end{array}$ & $\begin{array}{c}\text { FFFF, FFFS, FFSF, FFSS, FSFF, FSFS, } \\
\text { FSSF, FSSS, SFFF, SFFS, SFSF, SFSS, } \\
\text { SSFF, SSFS, SSSF, SSSS (VVVV) }\end{array}$ & 19.55 \\
\hline Recent cropland & $\begin{array}{l}\text { Conversion from forest or } \\
\text { savannah to cropland } \\
\text { between } 2003 \text { and } 2016\end{array}$ & $\begin{array}{l}\text { FFFC, FFSC, FSFC, FSSC, SFFC, } \\
\text { SFSC, SSFC, SSSC, (VVVC) }\end{array}$ & 20.87 \\
\hline Recent reforestation & $\begin{array}{l}\text { Abandoned cropland } \\
\text { between } 2003 \text { and } 2016\end{array}$ & CCCF, CCCS (CCCV) & 0.01 \\
\hline Cropland-fallow cycle & $\begin{array}{c}\text { Old and recent } \\
\text { Cropland-fallow cycles }\end{array}$ & $\begin{array}{c}\text { FFCF, FFCS, FSCF, FSCS, SSCF, } \\
\text { SSCS, SFCF, SFCS, FCCF, FCCS, } \\
\text { SCCF, SCCS, CFCF, CFCS, CSCF, } \\
\text { CSCS, FCFC, FCSC, SCFC, SCSC, } \\
\text { CFFC, CFSC, CSFC, CSSC, CCFC, } \\
\text { CCSC FCFF, FCFS, FCSF, FCSS, } \\
\text { SCFF, SCFS, SCSF, SCSS (VVCV, } \\
\text { VCCV, CVCV VCVC, CVVC, } \\
\text { CCVC, VCVV) }\end{array}$ & 0.98 \\
\hline Young cropland & $\begin{array}{l}\text { At least 13-years } \\
\text { permanent cropland from } \\
\text { forest or savannah } \\
\text { At }\end{array}$ & $\begin{array}{c}\text { FFCC, FSCC, SFCC, SSCC, CFCC, } \\
\text { CSCC (VVCC) }\end{array}$ & 22.54 \\
\hline Young reforestation & $\begin{array}{l}\text { permanent forest or } \\
\text { savannah from cropland }\end{array}$ & CCFF, CCFS, CCSF, CCSS (CCVV) & 0.3 \\
\hline Old cropland & $\begin{array}{l}\text { At least 30-years } \\
\text { permanent cropland from } \\
\text { forest or savannah }\end{array}$ & FCCC, SCCC (VCCC) & 7.23 \\
\hline Old reforestation & $\begin{array}{l}\text { At least 30-years } \\
\text { permanent forest or } \\
\text { savannah from cropland }\end{array}$ & $\begin{array}{l}\text { CFFF, CFFS, CFSF, CFSS, CSFF, } \\
\text { CSFS, CSSF, CSSS (CVVV) }\end{array}$ & 1.52 \\
\hline Other & $\begin{array}{l}\text { Any conversion involving } \\
\text { settlements and water }\end{array}$ & $\mathrm{OOOO}(\mathbf{0 O O O})$ & 1.72 \\
\hline
\end{tabular}

Bold codes in brackets correspond to the trajectories by combining savannah and forest in a single vegetation class (C: Cropland, F: Forest, S: Savannah, O: Other). 
Appendix C. Accuracy Assessment Summary Table (A3: 1974; A4: 1986; A5: 2003, and A6: 2016)

Table A3. Summary table of Unbiased Accuracy Assessment of LULC Map of categories in and around the Togodo Protected Area in 1974

\begin{tabular}{cccccc}
\hline $\mathbf{1 9 7 4}$ & \multicolumn{5}{c}{ Unbiased Accuracy Assessment Summary } \\
\hline Class & $\begin{array}{c}\text { Estimated Area } \\
\text { (hectares) }\end{array}$ & $\pm 95 \%$ CI & $\begin{array}{c}\text { User's } \\
\text { Accuracy }(\%)\end{array}$ & $\begin{array}{c}\text { Producer's } \\
\text { Accuracy }(\%)\end{array}$ & $\begin{array}{c}\text { Overall } \\
\text { Accuracy (\%) }\end{array}$ \\
\hline Forest & $10,732.15$ & 1930.04 & 82.98 & 64.86 & \\
Savannah & $63,264.99$ & 4209.65 & 76.35 & 86.36 & 76.79 \\
Cropland & $45,095.79$ & 4125.06 & 76.27 & 66.59 & \\
Built area & 230.05 & 435.98 & 90.00 & 3.31 & \\
\hline
\end{tabular}

Table A4. Summary table of Unbiased Accuracy Assessment of LULC Map of categories in and around the Togodo Protected Area in 1986

\begin{tabular}{cccccc}
\hline $\mathbf{1 9 8 6}$ & \multicolumn{5}{c}{ Unbiased Accuracy Assessment Summary } \\
\hline Class & $\begin{array}{c}\text { Estimated Area } \\
\text { (hectares) }\end{array}$ & $\pm 95 \%$ CI & $\begin{array}{c}\text { User's } \\
\text { Accuracy }(\%)\end{array}$ & $\begin{array}{c}\text { Producer's } \\
\text { Accuracy }(\%)\end{array}$ & $\begin{array}{c}\text { Overall } \\
\text { Accuracy }(\%)\end{array}$ \\
\hline Forest & $11,993.92$ & 3206.37 & 85.37 & 71.09 & \\
Savannah & $59,441.17$ & 6240.03 & 81.52 & 91.59 & \\
Cropland & $45,268.91$ & 6206.11 & 83.08 & 76.92 & $\mathbf{8 2 . 4 6}$ \\
Built area & 966.82 & 1264.85 & 90.00 & 33.30 & \\
Water & 1652.23 & 1903.04 & 100.00 & 17.04 & \\
\hline
\end{tabular}

Table A5. Summary table of Unbiased Accuracy Assessment of LULC Map of categories in and around the Togodo Protected Area in 2003

\begin{tabular}{cccccc}
\hline $\mathbf{2 0 0 3}$ & \multicolumn{4}{c}{ Unbiased Accuracy Assessment Summary } & \\
\hline Class & $\begin{array}{c}\text { Estimated Area } \\
\text { (hectares) }\end{array}$ & $\pm 95 \%$ CI & $\begin{array}{c}\text { User's } \\
\text { Accuracy }(\%)\end{array}$ & $\begin{array}{c}\text { Producer's } \\
\text { Accuracy (\%) }\end{array}$ & $\begin{array}{c}\text { Overall } \\
\text { Accuracy (\%) }\end{array}$ \\
\hline Forest & 7978.36 & 2079.01 & 94.44 & 73.87 & \\
Savannah & $43,660.68$ & 4237.93 & 88.10 & 89.09 & \\
Cropland & $66,374.16$ & 4133.94 & 91.79 & 94.11 & $\mathbf{9 0 . 5}$ \\
Built area & 984.22 & 996.09 & 91.38 & 48.40 & \\
Water & 325.62 & 59.33 & 88.24 & 97.24 & \\
\hline
\end{tabular}

Table A6. Summary table of Unbiased Accuracy Assessment of LULC Map of categories in and around the Togodo Protected Area in 2016

\begin{tabular}{cccccc}
\hline $\mathbf{2 0 1 6}$ & \multicolumn{5}{c}{ Unbiased Accuracy Assessment Summary } \\
\hline Class & $\begin{array}{c}\text { Estimated Area } \\
\text { (hectares) }\end{array}$ & $\pm 95 \%$ CI & $\begin{array}{c}\text { User's } \\
\text { Accuracy }(\%)\end{array}$ & $\begin{array}{c}\text { Producer's } \\
\text { Accuracy (\%) }\end{array}$ & $\begin{array}{c}\text { Overall } \\
\text { Accuracy (\%) }\end{array}$ \\
\hline Forest & 7608.59 & 1053.31 & 88.78 & 81.61 & \\
Savannah & $19,283.23$ & 1849.80 & 83.48 & 85.27 & \\
Cropland & $26,252.27$ & 1653.63 & 90.95 & 89.66 & \\
Fallow & $37,250.36$ & 2218.50 & 88.70 & 87.73 & $\mathbf{8 8 . 0 8}$ \\
Plantation & $27,580.33$ & 1883.61 & 87.42 & 91.21 & \\
Built area & 989.38 & 361.85 & 92.31 & 73.71 & \\
Water & 358.88 & 20.95 & 100.00 & 95.77 & \\
\hline
\end{tabular}

\section{References}

1. Assessment, M.E. Ecosystems and Human Well-Being: Synthesis; Island Press: Washington, DC, USA, 2005; ISBN 978-1-59726-040-4.

2. Ojima, D.S.; Galvin, K.A.; Turner, B.L. The global impact of land-use change. Bioscience 1994, 44, 300-304. [CrossRef] 
3. Foley, J.A.; DeFries, R.; Asner, G.P.; Barford, C.; Bonan, G.; Carpenter, S.R.; Chapin, F.S.; Coe, M.T.; Daily, G.C.; Gibbs, H.K.; et al. Global consequences of land use. Science 2005, 309, 570-574. [CrossRef] [PubMed]

4. Lambin, E.F.; Geist, H.J. Land-Use and Land-Cover Change: Local Processes and Global Impacts; Springer Science \& Business Media: Berlin/Heidelberg, Germany, 2008; ISBN 3-540-32202-7.

5. Wang, W.; Zhang, C.; Allen, J.M.; Li, W.; Boyer, M.A.; Segerson, K.; Silander, J.A. Analysis and prediction of land use changes related to invasive species and major driving forces in the state of connecticut. Land 2016, 5, 25. [CrossRef]

6. Lambin, E.F.; Geist, H.J.; Lepers, E. Dynamics of land-use and land-cover change in tropical regions. Annu. Rev. Environ. Resour. 2003, 28, 205-241. [CrossRef]

7. Li, W.; MacBean, N.; Ciais, P.; Defourny, P.; Lamarche, C.; Bontemps, S.; Houghton, R.A.; Peng, S. Gross and net land cover changes in the main plant functional types derived from the annual ESA CCI land cover maps (1992-2015). Earth Syst. Sci. Data 2018, 10, 219-234. [CrossRef]

8. Turner, B.L.; Meyer, W.B.; Skole, D.L. Global land-use/land-cover change: Towards an integrated study. Ambio Stockh. 1994, 23, 91-95.

9. Deng, X.; Li, Z. A review on historical trajectories and spatially explicit scenarios of land-use and land-cover changes in China. J. Land Use Sci. 2016, 11, 709-724. [CrossRef]

10. Ouedraogo, I.; Savadogo, P.; Tigabu, M.; Cole, R.; Odén, P.C.; Ouadba, J.-M. Trajectory Analysis of Forest Cover Change in the Tropical Dry Forest of Burkina Faso, West Africa. Landsc. Res. 2011, 36, 303-320. [CrossRef]

11. Uuemaa, E.; Antrop, M.; Roosaare, J.; Marja, R.; Mander, Ü. Landscape Metrics and Indices: An Overview of Their Use in Landscape Research. Living Rev. Landsc. Res. 2009, 3, 1-28. [CrossRef]

12. Huang, B.; Huang, J.; Pontius, R.G.; Tu, Z. Comparison of Intensity Analysis and the land use dynamic degrees to measure land changes outside versus inside the coastal zone of Longhai, China. Ecol. Indic. 2018, 89, 336-347. [CrossRef]

13. Badjana, H.M.; Helmschrot, J.; Selsam, P.; Wala, K.; Flügel, W.-A.; Afouda, A.; Akpagana, K. Land cover changes assessment using object-based image analysis in the Binah River watershed (Togo and Benin). Earth Space Sci. 2015, 2, 403-416. [CrossRef]

14. Mitsuda, Y.; Ito, S. A review of spatial-explicit factors determining spatial distribution of land use/land-use change. Landsc. Ecol. Eng. 2011, 7, 117-125. [CrossRef]

15. Hernández-Moreno, Á.; Miranda, M.D.; Arellano, E.; Dobbs, C. Landscape trajectories and their effect on fragmentation for a Mediterranean semi-arid ecosystem in Central Chile. J. Arid. Environ. 2016, 127, 74-81. [CrossRef]

16. Disperati, L.; Virdis, S.G. Assessment of land-use and land-cover changes from 1965 to 2014 in Tam Giang-Cau Hai Lagoon, central Vietnam. Appl. Geogr. 2015, 58, 48-64. [CrossRef]

17. Diwediga, B.; Agodzo, S.; Wala, K.; Le, Q.B. Assessment of multifunctional landscapes dynamics in the mountainous basin of the Mo River (Togo, West Africa). J. Geogr. Sci. 2017, 27, 579-605. [CrossRef]

18. Akpagana, K.; Guelly, K.A.; Gumedzoe, Y.M. Une adventice en voie d'envahissement du Territoire togolais: Eupatorium odoratum L. [syn. Chromolaena odorata (L.) R.M. King \& Robinson] (Compositae). Acta Bot. Gallica 1993, 140, 535-543. [CrossRef]

19. Vilà, M.; Ibáñez, I. Plant invasions in the landscape. Landsc. Ecol. 2011, 26, 461-472. [CrossRef]

20. Ramankutty, N.; Graumlich, L.; Achard, F.; Alves, D.; Chhabra, A.; DeFries, R.; Foley, J.A.; Geist, H.; Houghton, R.A.; Goldewijk, K.K.; et al. Global land-cover change: Recent progress, remaining challenges. In Land-Use and Land-Cover Change; Springer: Berlin/Heidelberg, Germany, 2006; pp. 9-39.

21. Kokou, K.; Caballé, G. Les îlots forestiers de la plaine côtière togolaise. Bois Forets Trop. 2000, 263 , 39-51. [CrossRef]

22. Atsri, H.; Konko, Y.; Cuni-Sanchez, A.; Abotsi, K.E.; Kokou, K. Changes in the West African forest-savanna mosaic, insights from central Togo. PLoS ONE 2018, 13, e203999. [CrossRef]

23. Laurin, G.V.; Puletti, N.; Hawthorne, W.; Liesenberg, V.; Corona, P.; Papale, D.; Chen, Q.; Valentini, R. Discrimination of tropical forest types, dominant species, and mapping of functional guilds by hyperspectral and simulated multispectral Sentinel-2 data. Remote Sens. Environ. 2016, 176, 163-176. [CrossRef]

24. Oszwald, J.; Antoine, L.; De Sartre, X.A.; Marcello, T.; Gond, V. Analyse des directions de changement des états de surface végétaux pour renseigner la dynamique du front pionnier de Maçaranduba (Brésil) entre 1997 et 2006. Télédétection 2010, 9, 97-111. 
25. Saadi, S.; Gintzburger, G. A spatial desertification indicator for Mediterranean arid rangelands: A case study in Algeria. Rangel. J. 2013, 35, 47. [CrossRef]

26. Müller-Wilm, U.; Devignot, O.; Pessiot, L. Sen2Cor Software Release Note. Ref. S2-PDGS-MPC-L2A-SRN-V2.3; ESA: Paris, France, 2016; Volume 1.

27. Huang, C.; Davis, L.S.; Townshend, J.R.G. An assessment of support vector machines for land cover classification. Int. J. Remote Sens. 2002, 23, 725-749. [CrossRef]

28. Mountrakis, G.; Im, J.; Ogole, C. Support vector machines in remote sensing: A review. ISPRS J. Photogramm. Remote Sens. 2011, 66, 247-259. [CrossRef]

29. Pal, M.; Mather, P.M. Support vector machines for classification in remote sensing. Int. J. Remote Sens. 2005, 26, 1007-1011. [CrossRef]

30. The Food and Agriculture Organization (FAO). Carte écologique du couvert végétal du Togo; The Food and Agriculture Organization: Rome, Italie, 1978.

31. Afidégnon, D.; Carayon, J.-L.; Fromard, F. Carte de la Végétation du Togo; Laboratoire de Botanique et Ecologie Végétale \& Laboratoire d'Ecologie Tropicale: Lomé, Togo, 2002.

32. Blaschke, T.; Hay, G.J. Object-oriented image analysis and scale-space: Theory and methods for modeling and evaluating multiscale landscape structure. Int. Arch. Photogram. Remote Sens. 2001, 34, 22-29.

33. Benz, U.C.; Hofmann, P.; Willhauck, G.; Lingenfelder, I.; Heynen, M. Multi-resolution, object-oriented fuzzy analysis of remote sensing data for GIS-ready information. ISPRS J. Photogramm. Remote Sens. 2004, 58, 239-258. [CrossRef]

34. Baatz, M.; Schäpe, A. Multiresolution segmentation: An optimization approach for high quality multi-scale image segmentation. In Angewandte Geographische Informations-Verarbeitung XII; Strobl, J., Blaschke, T., Griesebner, G., Eds.; Wichmann: Karlsruhe, Germany, 2000; pp. 12-23.

35. Robin, M. La Télédétection; Nathan: Paris, France, 1998.

36. Sparfel, L.; Gourmelon, F.; Le Berre, I. Approche orientée-objet de l'occupation des sols en zone côtière. Rev. Télédétection 2008, 8, 237-256.

37. Olofsson, P.; Foody, G.M.; Stehman, S.V.; Woodcock, C.E. Making better use of accuracy data in land change studies: Estimating accuracy and area and quantifying uncertainty using stratified estimation. Remote Sens. Environ. 2013, 129, 122-131. [CrossRef]

38. Pontius, R.G.; Millones, M. Death to Kappa: Birth of quantity disagreement and allocation disagreement for accuracy assessment. Int. J. Remote Sens. 2011, 32, 4407-4429. [CrossRef]

39. Braimoh, A.K.; Vlek, P.L.G. Land-cover change trajectories in northern Ghana. Environ. Manag. 2005, 36, 356-373. [CrossRef] [PubMed]

40. Pontius, J.R.G.; Gao, Y.; Giner, N.M.; Kohyama, T.S.; Osaki, M.; Hirose, K. Design and interpretation of intensity analysis illustrated by land change in central Kalimantan, Indonesia. Land 2013, 2, 351-369. [CrossRef]

41. Akodéwou, A.; Oszwald, J.; Akpavi, S.; Gazull, L.; Akpagana, K.; Gond, V. Problématique des plantes envahissantes au sud du Togo (Afrique de l'Ouest): Apport de l'analyse systémique paysagère et de la télédétection. Biotechnol. Agron. Société Environ. 2019, 23, 88-103. [CrossRef]

42. Zomlot, Z.; Verbeiren, B.; Huysmans, M.; Batelaan, O. Trajectory analysis of land use and land cover maps to improve spatial-temporal patterns, and impact assessment on groundwater recharge. J. Hydrol. 2017, 554, 558-569. [CrossRef]

43. Harris, I.; Jones, P.; Osborn, T.J.; Lister, D.H. Updated high-resolution grids of monthly climatic observationsThe CRU TS3.10 dataset. Int. J. Clim. 2013, 34, 623-642. [CrossRef]

44. Hirche, A.; Boughani, A.; Salamani, M. Évolution de la pluviosité annuelle dans quelques stations arides algériennes. Sci. Chang. Planétaires Sécheresse 2007, 18, 314-320. [CrossRef]

45. McKee, T.B.; Doesken, N.J.; Kleist, J. The relationship of drought frequency and duration to time scales. In Proceedings of the 8th Conference on Applied Climatology, American Meteorological Society, Boston, MA, USA, 17-22 January 1993; Volume 17, pp. 179-183.

46. Gremy, F.; Salmon, D. Bases Statistiques. Sciences Mathématiques au Service de la Médecine; Dunod: Paris, France, 1969.

47. Piquer-Rodríguez, M.; Butsic, V.; Gärtner, P.; Macchi, L.; Baumann, M.; Pizarro, G.G.; Volante, J.N.; Gasparri, I.; Kuemmerle, T. Drivers of agricultural land-use change in the Argentine Pampas and Chaco regions. Appl. Geogr. 2018, 91, 111-122. [CrossRef] 
48. Huang, J.; Pontius, R.G.; Li, Q.; Zhang, Y. Use of intensity analysis to link patterns with processes of land change from 1986 to 2007 in a coastal watershed of southeast China. Appl. Geogr. 2012, 34, 371-384. [CrossRef]

49. Aguirre-Gutiérrez, J.; Seijmonsbergen, A.C.; Duivenvoorden, J.F. Optimizing land cover classification accuracy for change detection, a combined pixel-based and object-based approach in a mountainous area in Mexico. Appl. Geogr. 2012, 34, 29-37. [CrossRef]

50. Chatelain, C.; Gautier, L.; Spichiger, R. A recent history of forest fragmentation in southwestern Ivory Coast. Biodivers. Conserv. 1996, 5, 37-53. [CrossRef]

51. Kpedenou, K.D.; Boukpessi, T.; Tchamie, T.T.K. Quantification des changements de l'occupation du sol dans la préfecture de Yoto (sud-est Togo) à l'aide de l'imagerie satellitaire Landsat. Rev. Sci. Environ. 2016, 13, 137-156.

52. Braimoh, A.K.; Vlek, P.L.G. Land-cover change analyses in the Volta Basin of Ghana. Earth Interact. 2004, 8, 1-17. [CrossRef]

53. Scheiter, S.; Higgins, S.I. Impacts of climate change on the vegetation of Africa: An adaptive dynamic vegetation modelling approach. Glob. Chang. Biol. 2009, 15, 2224-2246. [CrossRef]

54. Malahlela, O.E.; Cho, M.A.; Mutanga, O. Mapping the occurrence of Chromolaena odorata (L.) in subtropical forest gaps using environmental and remote sensing data. Biol. Invasions 2015, 17, 2027-2042. [CrossRef]

55. Dimobe, K.; Wala, K.; Batawila, K.; Dourma, M.; Agbelessessi, W.Y.; Akpagana, K. Analyse spatiale des différentes formes de pressions anthropiques dans la réserve de faune de l'Oti-Mandouri (Togo). VertigO Rev. Électronique Sci. Environ. 2012. [CrossRef]

56. Direction Générale de la Sûreté Nationale. Recensement Général de la Population et de l'Habitat au Togo. Résultats Définitifs; Direction Générale de la Sûreté Nationale: Lomé, Togo, 2010; p. 65.

57. Mainguet, M. Sécheresse, désertification et albédo des sols (drought, desertisation and soils albedo). Bull. Assoc. Géographes Fr. 1996, 73, 324-335. [CrossRef]

(C) 2020 by the authors. Licensee MDPI, Basel, Switzerland. This article is an open access article distributed under the terms and conditions of the Creative Commons Attribution (CC BY) license (http://creativecommons.org/licenses/by/4.0/). 